\title{
Distribution of viruses and their potential effect on bacterioplankton in an oligotrophic marine system
}

\author{
Núria Guixa-Boixereu, Dolors Vaqué, Josep M. Gasol, Carlos Pedrós-Alió \\ Departament de Biologia Marina i Oceanografia, Institut de Ciències del Mar, CSIC, Passeig Joan de Borbó s/n, \\ 08038 Barcelona, Spain
}

\begin{abstract}
Diel and spatial variability in the concentration of virus-like particles (VLP) was determined in a transect from the coast to offshore in the western Mediterranean ( 7 stations and 6 depths per station). VLP abundance in coastal waters was on average $1.6 \times 10^{7} \mathrm{VLP} \mathrm{ml}^{-1}$, in offshore stations this value was $1.2 \times 10^{7} \mathrm{VLP} \mathrm{m}^{-1}$. At the coastal station there was no varaibility in VLP abundance, bacterial abundance or chlorophyll a concentration through the water column, while offshore VLP decreased with depth. No clear diel pattern was found in 3 representative stations where diel cycles were studied. Viral impact on the bacterial assemblage was estimated at 2 depths (surface and deep chlorophyll $a$ maximum) of the latter 3 stations using 2 approaches: the percentage of visibly infected bacteria and viral decay rates in cyanide amended cultures. Visibly infected bacteria could not be detected in any sample after counting 300 cells per sample, implying that the percentage of visibly infected bacteria was lower than $0.3 \%$. Using the maximal conversion factor to convert this value to bacterial mortality we found that viruses could be responsible at mosi for $21.5 \%$ of the whole bacterial mortality. We calculated a hypothetical viral decay rate if the maximal possible impact of viruses $(21.5 \%)$ were true. This value corresponded to $0.02 \mathrm{~h}^{-1}$. However, using the cyanide method to measure viral decay rate, no significant decrease could be detected in a total of 8 viral decay experiments. In conclusion, the percent of total bacterial mortality due to viral lysis in the oligotrophic northwestern Mediterranean was low, certainly much lower than $20 \%$.
\end{abstract}

KEY WORDS: Oligotrophy · Mediterranean Sea · Virus-like particles (VLP) - Diel cycles · Viral decay · Viral impact

\section{INTRODUCTION}

Open oligotrophic waters constitute the largest portion of the world ocean. Virus-like particles (VLP) were found to be surprisingly abundant in such waters when single samples from different environments were examined for viral concentration (Bergh et al. 1989, Proctor \& Fuhrman 1990, Hara et al. 1991, Noble \& Fuhrman 1998). Some additional open water samples have been examined for VLP abundance in the context of the development of methods (Steward et al. 1992b, Hara et al. 1996, Weinbauer \& Suttle 1997). However, few studies (Boehme et al. 1993, Cochlan et al. 1993) have determined the distribution of VLP in open waters.

\footnotetext{
-Addressee for correspondence. E-mail: cpedros@icm.csic.es
}

Viruses have been shown to account for a high percentage of bacterial mortality in some marine environments (Proctor \& Fuhrman 1990, Weinbauer \& Peduzzi 1995), even similar to that due to heterotrophic nanoflagellates when both sources of bacterial losses have been measured simultaneously (Fuhrman \& Noble 1995, Steward et al. 1996). Viral lysis of bacterioplankton does not just cause the removal of bacterial cells. It has been reported that mortality of microbes due to viral infection may have consequences for nutrient and energy cycling (Middelboe et al. 1996), for the control of species diversity (Thingstad et al. 1997), and for the exchange of genetic materials among bacteria in marine environments (Chiura 1997).

Although VLP abundance itself gives little information about viral impact on the host populations, concentration of viruses in seawater is essential informa- 
tion for the ecological study of an aquatic environment. Thus, VLP abundance has been shown to be closely coupled to the trophic characteristics of the system (Maranger \& Bird 1995, Weinbauer \& Suttle 1997). VLP abundance seems to decrease with increasing distance from the shore, as has been reported in Florida coastal waters (Boehme et al. 1993), in the California coast (Cochlan et al. 1993) and in the Gulf of Mexico (Weinbauer \& Suttle 1997). However, an opposite trend was found in the estuarine Gulf of Bothnia (Cochlan et al. 1993). In addition, mortality of bacteria due to viral infection has been shown to be higher in eutrophic than in oligotrophic environments (Weinbauer \& Peduzzi 1995). Therefore, it seems that VLP abundance indirectly reflects viral impact on the host populations. Yet, almost none of this information has been gathered from open-sea environments. Thus, almost nothing is known about the abundance and impact of viruses in one of the most extensive ecosystems on earth.

Common characteristics found in the major oceanic gyres of the Atlantic and Pacific oceans are the presence of a deep chlorophyll a (chl a) maximum (DCM) and permanent oligotrophic conditions (Cullen 1991). The Mediterranean Sea offers the same characteristics of oligotrophy and presence of a DCM within a short distance from the shore (Estrada et al. 1993, PedrósAlió et al. 1999). Thus, the Mediterranean constitutes a model for studying viral distribution and its impact on bacterioplankton in oligotrophic open-sea waters.

The objectives of this work were (1) to determine VLP distribution in a transect from the coast to the open sea in the northwestern Mediterranean, (2) to study the relationships between VLP abundance and other components of the microbial food web, (3) to investigate possible changes in VLP abundance along diel cycles in representative stations of this transect and (4) to estimate the impact of viruses on the bacterial assemblage.

\section{MATERIALS AND METHODS}

Samples were collected along a transect in the northwestern Mediterranean Sea between June 6 and June 24 (1995) on board BiO 'Hespérides' (Fig. 1). Three stations were selected along the transect to study diel cycles and bacterial mortality due to viral infection. These stations represented the 3 main zones: the shelf coastal waters (Stn C), the slope frontal zone (Stn S) and the offshore 'deep' zone (Stn D). The characteristics of the microbial populations at these 3 stations have been described in Pedrós-Alió et al. (1999). Diel cycles of VLP abundance were followed at the 3 stations by taking samples at midnight and noon during a $24 \mathrm{~h}$ period. A detailed description of the data on bac-

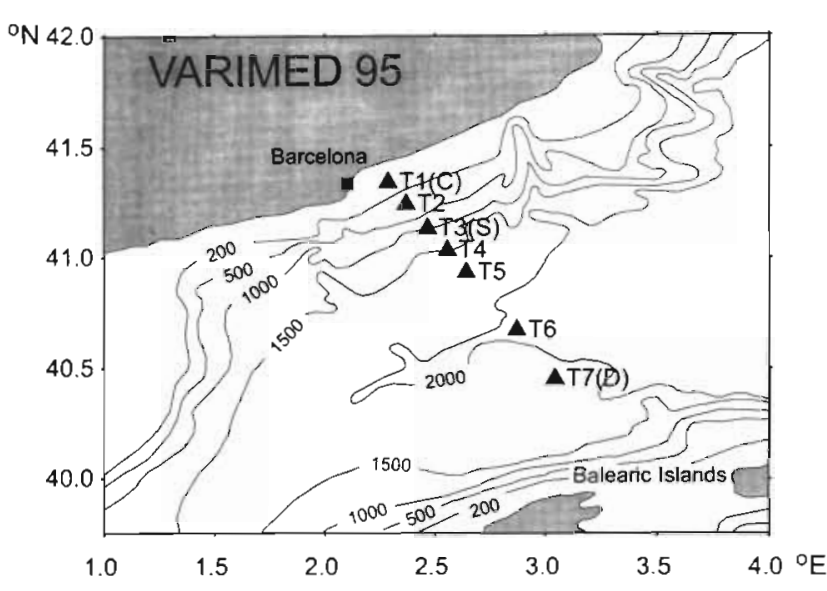

Fig. 1. Map of the area studied during cruise VARIMED 95. The transect follows a line between the city of Barcelona and the channel between the islands of Mallorca and Menorca. Stations where vertical profiles were studied are marked as T1 to T7. At T1 (C: coastal), T3 (S: slope) and T7 (D: deep) diel cycles were investigated. Depth is shown in meters

teria, chlorophyll and other parameters during these diel cycles can be found in Gasol et al. (1998). Vertical profiles of temperature, salinity and fluorescence were taken with a MarkII CTD. Water samples were taken with 121 Niskin bottles in a rosette.

$\mathrm{Chl}$ a was determined fluorometrically in $100 \mathrm{ml}$ samples that were filtered through GF/F glass fiber filters and frozen. The filters were extracted overnight in $90 \%$ acetone at $4^{\circ} \mathrm{C}$, and fluorescence of the extract measured with a Turner Designs fluorometer (Yentsch \& Menzel 1963).

Samples for bacterial abundance were fixed with glutaraldehyde ( $1 \%$ final concentration) in polypropylene bottles. Bacteria were stained with DAPI $\left(1 \mu \mathrm{g} \mathrm{ml}^{-1}\right.$ final concentration) and filtered onto black $0.2 \mu \mathrm{m}$ pore size polycarbonate filters (Porter \& Feig 1980), mounted on microscope slides and frozen. Bacterial abundance was determined with a Nikon epifluorescence microscope at a magnification of 1250x. About 200 to 300 bacteria were counted per sample.

Abundance of VLP was determined by YOPRO (YO-PRO 1, Molecular Probes) stain and epifluorescence microscopy (Hennes \& Suttle 1995). Unfixed $100 \mu$ samples were immediately diluted with $700 \mu$ lof Milli-Q water filtered through $0.02 \mu \mathrm{m}$ pore size Anodisc filters. Each diluted sample was gently filtered through a $0.02 \mu \mathrm{m}$ pore size Anodisc 25 filter. The Anodisc filters with the filtered sample were laid on $80 \mu \mathrm{l}$ of the staining solution (YO-PRO 1,50 $\mu \mathrm{M}$ final concentration) in a Petri dish and incubated in the dark for $2 \mathrm{~d}$ at room temperature. The filters were then washed twice by filtering $800 \mu \mathrm{l}$ of Milli-Q water through the membrane. Filters were transferred to glass slides and immediately covered with a drop of 
spectrophotometric-grade glycerol and a cover slip. Filters were stored at $-20^{\circ} \mathrm{C}$ until counted. VLP abundance was determined with an epifluorescence microscope at a magnification of $1250 \times$ with blue light ex citation and a barrier filter. The counting error of the method was calculated by counting 3 filters from the samples corresponding to surface and DCM waters at the 3 representative stations. The error was calculated as a percentage of the mean.

In order to measure the impact of viruses on the bacterial assemblage in the Mediterranean, we tried 2 different methods: the counting of visibly infected bacteria (Weinbauer et al. 1993) and the measurement of viral decay rates in KCN amended cultures (Heldal \& Bratbak 1991). For the counting of visibly infected bacteria, cells and viruses were harvested onto grids (400-mesh Ni electron microscope grids with carbon coated formvar film) using a Beckman SW41 swing-out rotor run at $100000 \times g$ for $30 \mathrm{~min}$ at $20^{\circ} \mathrm{C}$ (Heldal \& Bratbak 1991, Weinbauer et al. 1993). For each sample, duplicate grids were stained for $1 \mathrm{~min}$ with uranyl acetate $(2 \% \mathrm{w} / \mathrm{w})$. We tried to count infected bacteria by observing the whole cells in a Hitachi 600 transmission electron microscope (TEM) operated at $80 \mathrm{kV}$ and at a magnification of $20000 \times$ according to Weinbauer et al. (1993). At least 300 cells in each sample were inspected for potential infection.

Incubations for VLP decay experiments were carried out in 1 I Whirl-Pack polyethylene bags, which let $70 \%$ UV radiation through. Parallel bags were covered with aluminum foil for dark incubations. VLP decay was recorded after inhibiting production of new viruses by adding $\mathrm{KCN}$ to a final concentration of $2 \mathrm{mM}$ ('dead' cultures, Heldal \& Bratbak 1991). Two experiments were carried out with surface waters and one with water from the DCM in each representative station (Stns C, S, D). For surface waters, one experiment was performed in the dark and the other in the light. For the DCM only the dark condition was considered. Parallel to the 'dead' cultures we had 'live' cultures, used as controls. Both, dead and live cultures were incubated in a tub on deck with running surface water. Samples for counting VLP were taken at 2 to $3 \mathrm{~h}$ intervals for the first $14 \mathrm{~h}$ of the experiment. After this time, samples were taken less frequently until the end of the experiments. Samples for ${ }^{3} \mathrm{H}$-leucine incorporation were taken at the beginning and at the end of each experiment in order to make sure that microbial activity was stopped by KCN.

\section{RESULTS}

Depth profiles of chl $\boldsymbol{a}$, and bacterial and VLP abundances are shown in Fig. 2. The coastal station (C) showed a uniform abundance in VLP and bacteria throughout the water column. The other stations followed a different pattern, with peaks of chl $a_{1}$ bacterial and VLP abundance at different depths. The peak of chl a (DCM) was usually sharp and could be found between 40 and $70 \mathrm{~m}$ depending on the station. The peak of bacteria was less sharp and it was found either slightly above the DCM (T4, T6) or coincident with it (T2, T5, T7). The distribution of viruses was more variable from one station to another. In some cases (T4, T6, T7) a peak of VLP was coincident with the maximal bacterial abundance. At other stations (T3, T5), the VLP concentrations decreased smoothly with depth from the surface. Finally, no clear pattern was detected, in some profiles (T1, T2).

Values of VLP abundance ranged between $5 \times 10^{6}$ and $3 \times 10^{7}$ along the transect. Changes in VLP abundance were minimal at the 2 depths sampled below $60 \mathrm{~m}$ at all the stations. The VLP/BN ratio ranged from 10 to 80 (Fig. 2). The depth distribution of VLP/BN was parallel to that of VLP abundance.

Relationships between bacterial and VLP abundance and between chl $a$ and VLP abundance were not significant for the coastal stations ( $T 1, T 2, n=11, p=0.4$ ) and the intermediate stations (T3, T4, $\mathrm{n}=11, \mathrm{p}=0.2)$. For the offshore stations (T5, T6, T7), VLP and bacterial abundance showed a significant relationship ( $\mathrm{n}=18$, $\mathrm{p}<0.0009, \mathrm{r}^{2}=0.506$ ). The relationship between $\mathrm{chl} a$ and VLP abundance was also significant in the latter stations $\left(n=18, p<0.0061, r^{2}=0.38\right)$.

Integrated values of chl a concentration, and bacterial and VLP abundances from the surface to $70 \mathrm{~m}$ (coastal station) or $200 \mathrm{~m}$ (slope and open-sea stations) showed a similar pattern (Fig. 3). Peaks with maximal concentration of these parameters were coincident in Stns T1 and T4.

No clear pattern in diel variability of VLP abundance was found at any of the stations (Fig. 4). At the coastal and slope stations VLP abundance showed small changes with depth in both diel cycles. At the coastal station, VLP was slightly higher at night than during the day in the first diel cycle (Fig. 4; C1, C2). At the slope station each diel cycle showed a different pattern (Fig. $4 ;$ S1, S2). During the day the peak of maximal VLP abundance at $20 \mathrm{~m}$ appeared both times. At night, however, the first diel cycle showed a minimum at $50 \mathrm{~m}$ and the second a maximum at $60 \mathrm{~m}$. At the deep station (Fig. 4; D1, D2), no diel cycles were found. However, VLP abundance showed slightly higher values at night in the upper mixed layer. At this station, patterns of VLP abundance with depth were similar in both cycles.

Viral decay experiments carried out at the deep station are presented in Fig. 5 as an example. An analysis of covariance (ANCOVA) was used to test for differences between dead and control cultures in each 

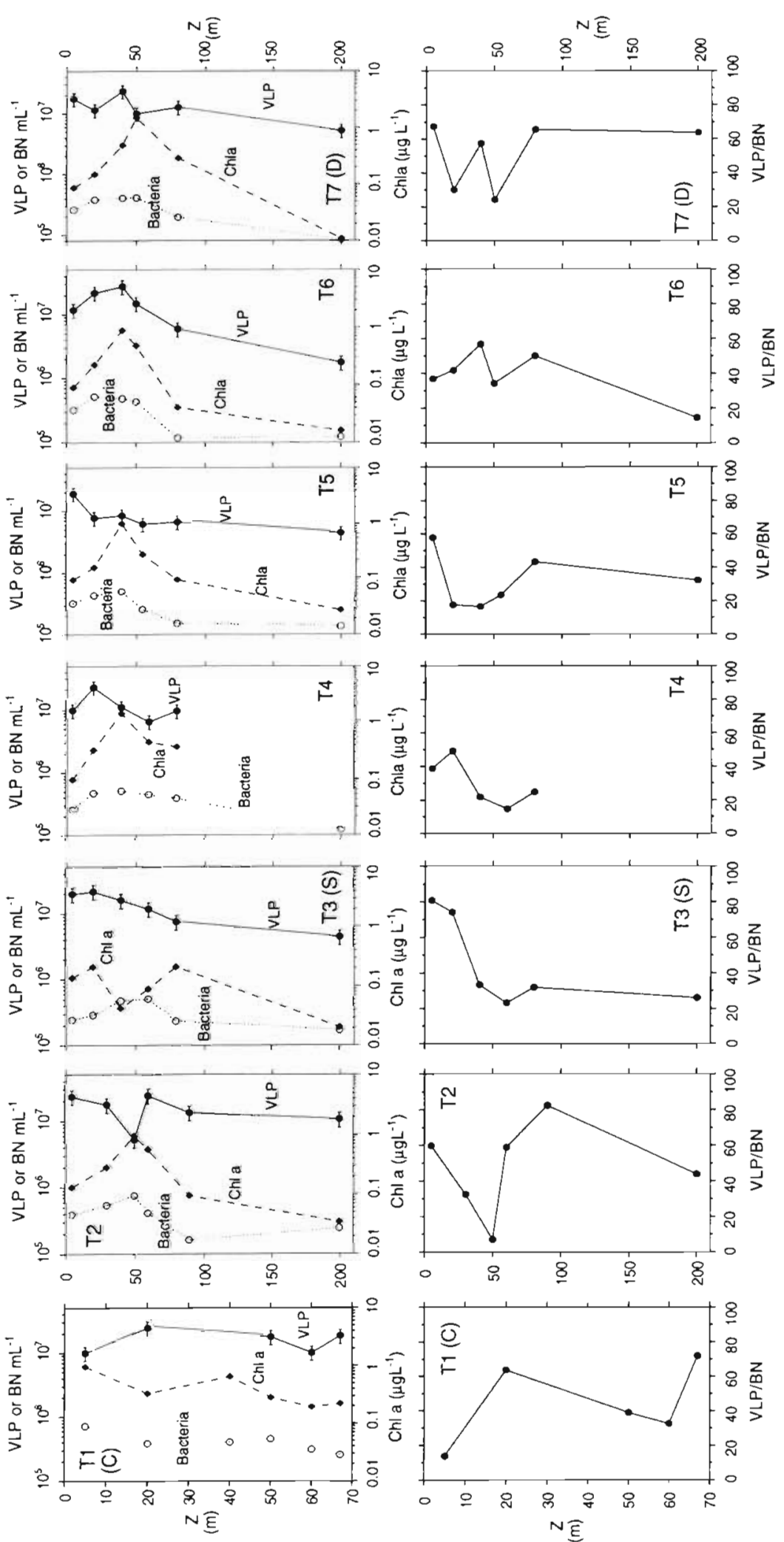

experiment (surface water and light, surface water and dark, DCM water and dark). Previously the data were log transformed to fulfill normality assumptions required by the statistical analysis. We did not find any significant differences $(p>0.05)$ using the whole data set or the data from the first $20 \mathrm{~h}$ alone. At the other stations ( $\mathrm{C}$ and $\mathrm{S}$ ), where experiments of viral decay were also carried out, we obtained the same results.

\section{DISCUSSION}

The values of VLP abundance reported in the present work are difficult to compare directly with similar studies because of the different methodologies used to count VLP (Table 1). Obviously, the method used to count viruses must be taken into account in order to compare results from different studies. It has been suggested that TEM counts could underestimate VLP abundance in natural environments (Hennes \& Suttle 1995, Weinbauer \& Suttle 1997). However, at the time being, there are very few studies that have used YOPRO to estimate viral abundance in aquatic environments. Most of the studies in the literature have used TEM to estimate VLP abundance in nature. To be able to compare our data counted by epifluorescence microscopy with those reported in previous work, we show our YOPRO counts converted to TEM counts in Table 1 (using the regression line shown in Fig. 6). The data used to build the regression line corresponded to a microcosm experiment (Guixa-Boixereu et al. 1999) plus data from the only 2 studies that compared both methods (Hennes \& Suttle 1995, Weinbauer \& Suttle 1997).

After conversion of the VLP abundance found with YOPRO to TEM, values of VLP abundance were 2 to 5 times lower than those found with YOPRO. This was in agreement with Hennes \& Suttle (1995), who compared viral abundance from different 


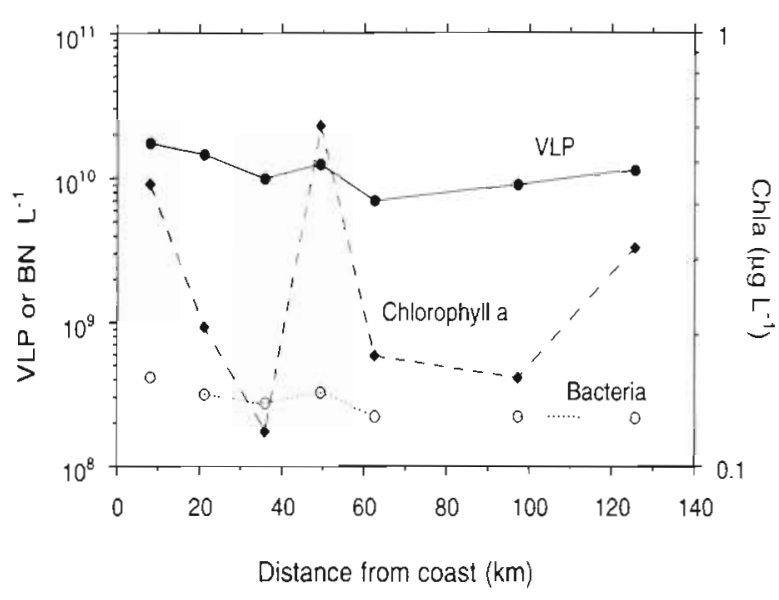

Fig. 3. Integrated values of VLP (VLP l-1) and bacterial abundance $\left(\mathrm{BN}^{-1}\right.$ ) and chlorophyll a (chl a $\mu \mathrm{g} \mathrm{l}^{-1}$ ) along the transect (distance from the coast in $\mathrm{km}$ ). Values for the whole water column were integrated and the result divided by the integration depth, thus obtaining weighted averages

environments with both methods. These converted values of VLP abundance in the Mediterranean were in the lower range of the reported numbers for opensea environments (Table 1). Values from some very oligotrophic seas, however, such as the Sargasso Sea and the Barents Sea, showed the lowest VLP abundance values reported: 2 to 3 orders of magnitude lower than values for the Mediterranean. Since such extremely low values have been found only twice, however, their general significance cannot be evaluated.

Boehme et al. (1993) also found a lower VLP abundance value in an offshore than in an inshore station in the Gulf of Mexico (Table 1). However, they concentrated the viruses from the natural sample by vortex flow filtration ( 30 to $100 \mathrm{kDa}$ pore size) and viral losses have been reported during this process (Paul et al. 1991, Suttle \& Chan 1994). Altogether, VLP abundance in the western Mediterranean was one of the lowest reported in marine environments.

VLP abundance did not show a marked decrease from coast to open sea. However, we found some differences between coast and open sea in the vertical distribution of VLP. The coastal station (Stn C) was different from the rest, because it did not show variability in VLP abundance through the water column. The slight variability in VLP abundance with depth in coastal samples was close to the average coefficient of variation (CV) of viral counting by YOPRO in this environment (average $\mathrm{CV}=25 \%$ ). Thus, we were not able to detect any statistically significant relationship between VLP and other components of the food web in coastal samples. This is reasonable because bacteria and chl a also showed very small changes with depth.

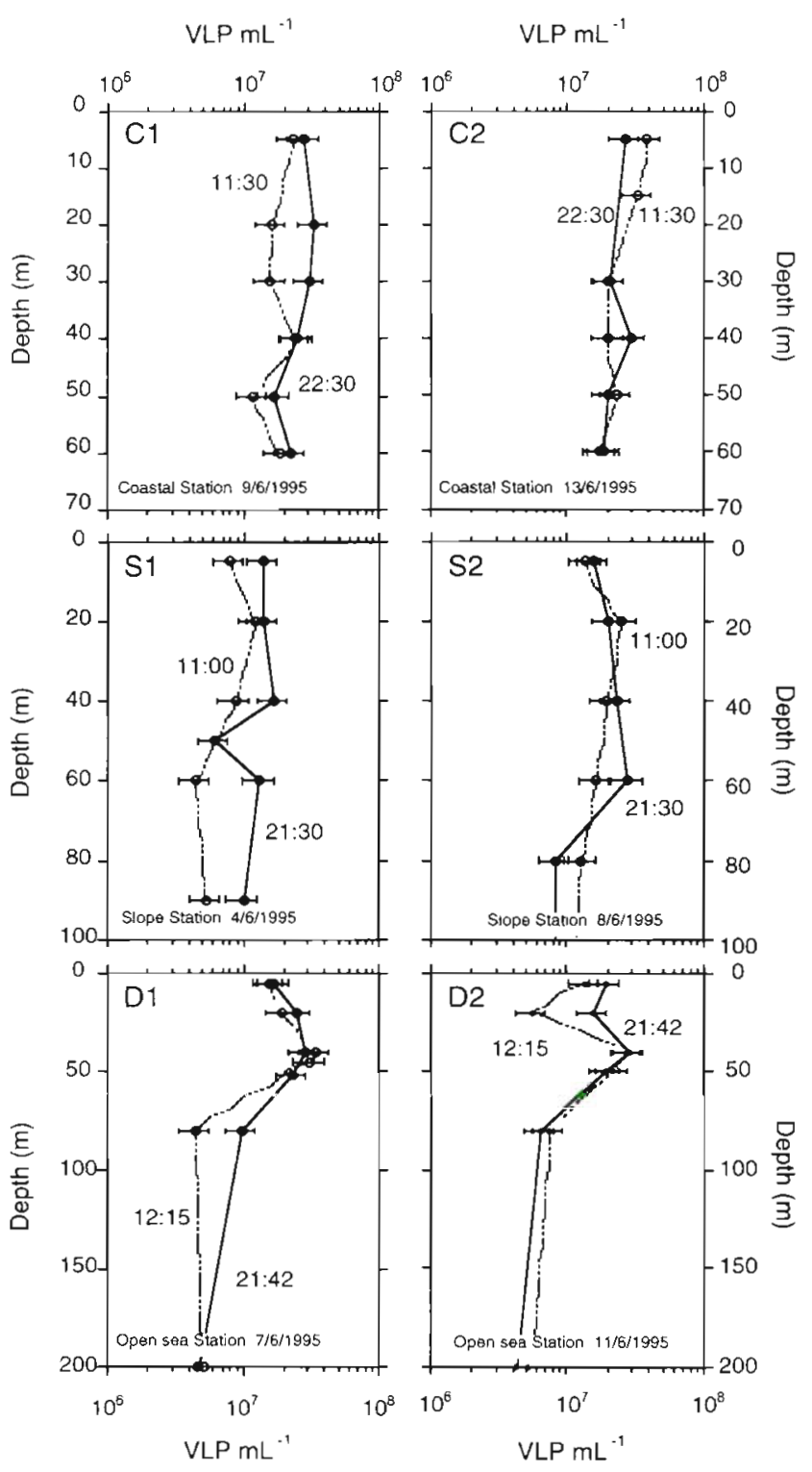

Fig. 4. Variability in VLP abundance during the diel cycles ( 1 and 2) investigated at the 3 stations: Stns C, S and D. Error bars indicate standard error, which was calculated as a percentage of the mean in selected triplicate samples

This could be the reason why the correlation between VLP abundance and chl $a$ and between VLP and bacterial abundance were only significant at the offshore stations. The fact that both relationships explained a low percentage of VLP variability at open-sea stations could indicate that part of the viral assemblage could be bacteriophages and the rest phytoplankton viruses.

Although bacteria and VLP were only correlated in the offshore samples, the integrated values of both parameters showed the same pattern along the transect. This indicates that VLP abundance is coupled to the other components of the microbial food web. 

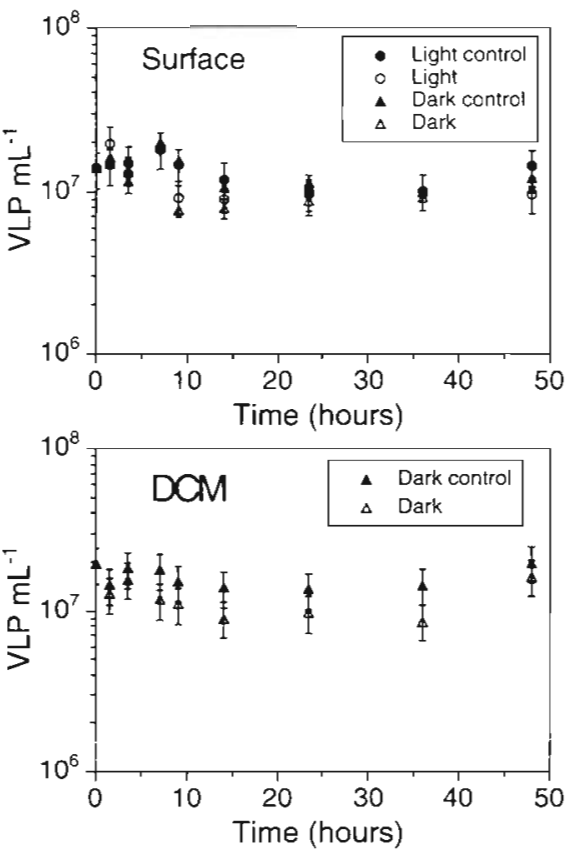

Fig. 5. Changes in VLP abundance (VLP $\mathrm{ml}^{-1}$ ) along the viral decay experiments performed at the deep station (D) with water from the surface $(5 \mathrm{~m})$ and deep chl a maximum (DCM) $(50 \mathrm{~m})$. Solid symbols indicate live cultures (control) and empty symbols dead cultures (with $\mathrm{KCN}$ ). Triangles refer to light incubations and circles correspond to dark conditions. Error bars indicate standard error, which was calculated as a percentage of the mean in selected triplicate samples

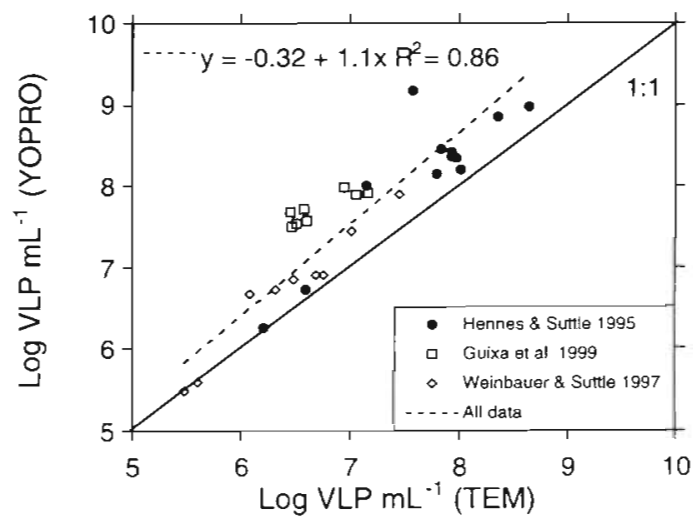

Fig. 6. Relationship between viral particles (log VLP $\mathrm{ml}^{-1}$ ) counted by transmission electron microscopy (TEM) and by epifluorescence microscopy in YOPRO stained samples. Solid line indicates a $1: 1$ relationship

No clear diel pattern was found at any of the stations. The slight differences found in VLP concentration between night and day at the coastal station are difficult to interpret because they only occurred once. At Stn $\mathrm{S}$ both diel cycles followed different patterns. However both cycles presented a minimum in VLP abundance close to the surface during the day, perhaps reflecting decay due to sunlight irradiation. At Stn D no diel cycles were found. Gasol et al. (1998), in their study of diel variability on bacterial activity during the same cruise, concluded that diel cycles in bacterial heterotrophic production were present at the offshore station while no diel pattern was found at the coastal station. Despite changes in activity, bacterial abundance did not show diel variations (Gasol et al. 1998). We only had 2 profiles, 12 h apart, per diel cycle. More profiles could have potentially shown a more significant pattern of variation. However, we think it unlikely, since bacterial abundance was measured 6 times during each cycle and no significant differences could be found (Gasol et al. 1998). Likewise, studies in other coastal areas (Jiang \& Paul 1994, Weinbauer et al. 1995) have not found diel variations in VLP. The latter studies corresponded to eutrophic environments where the concentration of bacteria and VLP were about an order of magnitude higher than those found in the Mediterranean.

In order to measure the impact of viruses on the bacterial assemblage in the Mediterranean, we tried 2 different methods: the counting of visibly infected bacteria and the measurement of viral decay rates in $\mathrm{KCN}$ amended cultures (see 'Materials and methods'). Previously, we had used both methods in some environments (Guixa-Boixereu et al. 1996, 1999, unpubl.). In the present study, we found no infected cells after counting 300 cells per sample in more than 10 samples. This meant that the percentage of visibly infected bacteria was lower than $0.3 \%$. The whole cell method (Weinbauer et al. 1993) for detecting infected cells has the advantage that the whole cell is examined, while in thin sections (Proctor et al. 1993) infected cells may appear as noninfected just because the particular section examined happened not to cut through any viral particle. On the other hand, the whole cell method has some problems. First, cells sometimes appear opaque to the electrons and this may cause some infected cells to be scored as noninfected, just because the viral particles are masked by the dark cell. The second problem is that cells can disrupt at very high centrifugation speeds (Weinbauer \& Höfle 1998a,b). The only direct comparison between the 2 methods is that carried out by Fuhrman \& Noble (1995), who compared the 2 options in 1 of their 2 mesocosms. They found 3.3 to $4.6 \%$ of visibly infected cells in thin sections and 0.7 to $1.5 \%$ in whole bacteria. Thus, the thin section method gave percentages which were between 3 and 5 times larger in these 2 cases. If the error were the same in the Mediterranean, we would have at most $0.3 \%$ times $5=1.5 \%$ infected cells. Proctor et al. (1993) provided a range of factors (7.4 to 14.3) to convert percent of infected cells to bacterial mortality. Using these factors 
Table 1. Values of virus-like particle (VLP) abundance, counting method used in each study, and VLP/bacterial abundance (BN) from different marine environments. Data within parentheses correspond to the transformed VLP abundance from YOPRO to TEM according to the regression line: $\log (\mathrm{VLP}-\mathrm{YOPRO})=-0.32+1.1 \log (\mathrm{VLP}-\mathrm{TEM})$

\begin{tabular}{|c|c|c|c|c|c|}
\hline \multirow[t]{2}{*}{ Location } & \multicolumn{4}{|c|}{ VLP $\mathrm{ml}^{-1}$} & \multirow[t]{2}{*}{ Source } \\
\hline & $\begin{array}{c}\text { Filter }^{\mathrm{C}}+\text { Spin }^{\mathrm{d}} \\
+ \\
\text { TEM }\end{array}$ & $\begin{array}{l}\text { Spin }^{d} \\
+ \\
\text { TEM }\end{array}$ & $\begin{array}{c}\text { YOPRO } \\
+ \\
\text { epifluorescence }\end{array}$ & VLP/BN & \\
\hline \multicolumn{5}{|l|}{ Gulf of Mexico } & \multirow[t]{3}{*}{ Boheme et al. (1993) } \\
\hline Coast & $2.60 \times 10^{6}$ & & & 3.1 & \\
\hline Off shore & $3.45 \times 10^{5}$ & & & 2.1 & \\
\hline \multicolumn{5}{|l|}{ Southern California Bight ${ }^{\mathfrak{a}}$} & \multirow[t]{3}{*}{ Cochlan et al. (1993) } \\
\hline Coast & & $7.20 \times 10^{6}$ & & 6.8 & \\
\hline Off shore & & $1.11 \times 10^{6}$ & & 2.4 & \\
\hline \multicolumn{5}{|l|}{ Gulf of Bothnia } & \multirow[t]{3}{*}{ Cochlan et al. (1993) } \\
\hline Coast & & $3.20 \times 10^{7}$ & & 14.7 & \\
\hline Off shore & & $3.15 \times 10^{7}$ & & & \\
\hline \multicolumn{5}{|l|}{ Gulf of Mexico ${ }^{b}$} & \multirow[t]{3}{*}{ Weinbauer \& Suttle (1997) } \\
\hline Coast & & $1.92 \times 10^{7}$ & $4.81 \times 10^{7}$ & & \\
\hline Off shore & & $1.72 \times 10^{6}$ & $3.09 \times 10^{6}$ & & \\
\hline \multicolumn{5}{|l|}{ Western Mediterraneañ } & \multirow[t]{3}{*}{ This study } \\
\hline Coast & & $\left(3.53 \times 10^{6}\right)$ & $1.60 \times 10^{7}$ & $49.9(10.1)$ & \\
\hline Off shore & & $\left(2.87 \times 10^{6}\right)$ & $1.24 \times 10^{7}$ & $39.7(8.3)$ & \\
\hline North Atlantic & & $1.50 \times 10^{7}$ & & 49.7 & Bergh et al. (1989) \\
\hline Barents Sea & & $<6.00 \times 10^{4}$ & & 3.0 & Bergh et al. (1989) \\
\hline Sargasso Sea & & $3.00 \times 10^{3}$ & & & Proctor \& Fuhrman (1990) \\
\hline Kuroshio area & & $\left(8.60 \times 10^{6}\right)$ & & 22.6 & Hara et al. (1991) \\
\hline \multicolumn{6}{|c|}{${ }^{a}$ Values corresponded to the mean from different vertical profiles } \\
\hline \multicolumn{6}{|c|}{ balues corresponded to the mean from surface waters } \\
\hline \multicolumn{6}{|c|}{ cultrafiltration } \\
\hline${ }^{\mathrm{d} U l t r a c e n t r i f u g a t i o n}$ & & & & & \\
\hline
\end{tabular}

with our maximal infection values, viruses would be responsible for less than 11.1 to $21.5 \%$ of the whole bacterial mortality.

We also tried to measure VLP decay rates in bottle incubations using cyanide as an inhibitor of biological activity, according to Heldal \& Bratbak (1991). This method was used by Heldal \& Bratbak (1991) in Raunefjorden and in Lake Kalandsvannet, and by Mathias et al. (1995) in a backwater system of the River Danube. Heldal \& Bratbak (1991) could not estimate the percentage of the total bacterial mortality caused by viral infection with the cyanide method because they did not measure bacterial heterotrophic production. The lowest decay rate measured by Mathias et al. (1995) was $0.06 \mathrm{~h}^{-1}$, implying that viruses could account for $15 \%$ of total bacterial mortality. In our experiments no significant decreases could be detected in a total of 6 viral decay experiments performed at Stns C, $\mathrm{S}$ and D (2 at each station, Fig. 1), using the cyanide method. If the maximal possible impact of viruses estimated from the visibly infected bacteria method were true $(21.5 \%)$, viral decay rates would be, in all the samples, always lower than $0.02 \mathrm{~h}^{-1}$. The fact that our esti- mated viral decay rates were not significantly different from $0(p>0.05)$ means that viral decay rates were still lower than these values. Thus, the impact of viruses should be certainly lower than $21.5 \%$ of the total bacterial mortality in the Mediterranean Sea.

There is a third method for estimating viral impact on the bacterial assemblage (Steward et al, 1992a,b). This method consists of measuring the incorporation of tritiated thymidine into viral DNA. With this method a viral production lower than $10^{9} \mathrm{VLP} \mathrm{l}^{-1} \mathrm{~d}^{-1}$ would not be detected. At the offshore stations where Steward et al. (1992b) applied this method, only 2 out of 8 samples showed detectable values of viral production. With the maximal impact of viral mortality over the bacterial population possible in the Mediterranean (21.5\%), viral production would be $8 \times 10^{7} \mathrm{VLP} \mathrm{l}^{-1} \mathrm{~d}^{-1}$ as a maximum. This value is not detectable by the method of Steward et al. (1992b).

In summary, bacterial mortality due to viral infection was found to be below the detection limits of current methods in the northwestern Mediterranean. Thus, viral impact in the Mediterranean has to be necessarily small, certainly much smaller than $20 \%$ of the total 
bacterial mortality. This is probably the case in most open sea waters, although development of finer techniques is needed before this point can be definitively proven.

Acknowledgements. We thank scientists and crew on board the BIO 'Hespérides' cruise VARIMED 95, especially M. Estrada and L. Arin for providing chlorophyll a measurements. This work was supported by grants AMB 94-1019 and 94-0853 from CICYT, PB91-075 from DGICYT and MAS2-CT93-0063 and MAS3-CT95-0016 grants from the EU. N.G.-B. was supported by an FI scholarship from the 'Generalitat de Catalunya'

\section{LITERATURE CITED}

Bergh $\varnothing$, Borsheim KY, Bratbak G, Heldal M (1989) High abundance of viruses found in aquatic environments. Nature 340:467-468

Boehme $J$, Frischer ME, Jiang SC, Kellogg CA, Pichard S, Rose JB, Steinway C, Paul JH (1993) Viruses, bacterioplankton, and phytoplankton in the southeastern Gulf of Mexico: distribution and contribution to oceanic DNA pools. Mar Ecol Prog Ser 97:1-10

Chiura HX (1997) Generalized gene transfer by virus-like particles from marine bacteria. Aquat Microb Ecol 16: $75-83$

Cochlan WP, Wikner J, Steward GF, Smith DC, Azam F (1993) Spatial distribution of viruses, bacteria and chlorophyll a in neritic, oceanic and estuarine environments. Mar Ecol Prog Ser 92:77-87

Cullen J (1991) Hypothesis to explain high nutrient, low chlorophyll conditions in the open sea. Limnol Oceanogr 36:1578-1599

Estrada M, Marrasé C, Latasa M, Berdalet E, Delgado M, Riera T (1993) Variability of deep chlorophyll maximum characteristics in the northwestern Mediterranean. Mar Ecol Prog Ser 92:289-300

Fuhrman JA, Noble RT (1995) Viruses and protists cause similar bacterial mortality in coastal seawater. Limnol Oceanogr 40:1236-1242

Gasol JM, Doval MD, Pinhassi J, Calderón-Paz JI, GuixaBoixereu N, Vaqué D, Pedrós-Alió C (1998) Diel variations in bacterial activity and growth in the northwestern Mediterranean sea. Mar Ecol Prog Ser 164:107-124

Guixa-Boixereu N, Calderón-Paz JI, Heldal M, Bratbak G, Pedrós-Alió C (1996) Viral lysis and bacterivory as prokaryotic loss factors along a salinity gradient. Aquat Microb Ecol 11:215-227

Guixa-Boixereu N, Lysnes K, Pedrós-Alió C (1999) Viral lysis and bacterivory during a phytoplankton bloom in a coastal water microcosm. Appl Environ Microbiol 65(5):1949-1958

Hara S, Terauchi K, Koike I (1991) Abundance of viruses in manine waters: assessment by epifluorescence and transmission electron microscopy. Appl Environ Microbiol 57: $2731-2734$

Hara S, Koike I, Terauchi K, Kamiya H, Tanoue E (1996) Abundance of viruses in deep oceanic waters. Mar Ecol Prog Ser 145:269-277

Heldal M, Bratbak G (1991) Production and decay of viruses in aquatic environments. Mar Ecol Prog Ser 72:205-212

Hennes KP. Suttle CT (1995) Direct counts of viruses in natural waters and laboratory cultures by epifluorescence microscopy. Limnol Oceanogr 40:1050-1055
Jiang SC, Paul JH (1994) Seasonal and diel abundance of viruses and occurrence of lysogeny/bacteriocinogeny in the marine environment. Mar Ecol Prog Ser 104:163-172

Maranger R, Bird DF (1995) Viral abundance in aquatic systems: a comparison between marine and fresh waters. Mar Ecol Prog Ser 121:217-226

Mathias CB, Kirschner AKT, Velimirov B (1995) Seasonal variations of virus abundance and viral control of the bacterial population in backwater system of the Danube river. Appl Environ Microbiol 61:3734-3740

Middelboe $M$, Jørgensen NOG, Kroer $N$ (1996) Effects of viruses on nutrient turnover and growth efficiency of noninfected marine bacterioplankton. Appl Environ Microbiol 62:1991-1997

Noble RT, Fuhrman JA (1998) Use of SYBR green for rapid epifluorescence counts of marine viruses and bacteria. Aquat Microb Ecol 14:113-118

Paul JH, Jiang SC, Rose JB (1991) Concentration of viruses and dissolved DNA from aquatic environments by vortex flow filtration. Appl Environ Microbiol 57:2197-2204

Pedrós-Alió C, Calderón-Paz JI, Guixa-Boixereu N, Estrada M, Gasol JM (1999) Relationships between bacterioplankton and phytoplankton biomass and production in the northwestern Mediterranean Sea during summer stratification. Deep-Sea Res I 46:985-1019

Porter KG, Feig YS (1980) The use of DAPI for identification and enumeration of bacteria and blue-green algae. Limnol Oceanogr 25:943-948

Proctor LM, Fuhrman JA (1990) Viral mortality of marine bacteria and cyanobacteria. Nature 343:60-62

Proctor LM, Okubo A, Fuhrman JA (1993) Calibrating estimates of phage-induced mortality in marine bacteria: ultrastructural studies of marine bacteriophage development from one-step growth experiments. Microb Ecol 25 $161-182$

Steward GF, Wikner J, Cochlan WP, Smith DC, Azam F (1992a) Estimation of virus production in the sea: I. Method development. Mar Microb Food Webs 6:57-78

Steward GF, Wikner J, Cochlan WP, Smith DC, Azam F (1992b) Estimation of virus production in the sea: II. Field results. Mar Microb Food Webs 6:79-90

Steward GF, Smith DC, Azam F (1996) Abundance and production of bacteria and viruses in the Bering and Chukchi Seas. Mar Ecol Prog Ser 131:287-300

Suttle CA, Chan AM (1994) Dynamics and distribution of cyanophages and their effect on marine Synechococcus spp. Appl Environ Microbiol 60:3167-3174

Thingstad TF, Bratbak G, Heldal M, Dundas I (1997) Trophic interactions controlling the diversity in pelagic microbial food webs. In: Martins MT, Zanoli MI, Tiedje JM, Norton LC, Döbereiner J, Sanchez P (eds) Progress in microbial ecology. Soc Brasil Microbiol, Sāo Paulo, p $107-114$

Weinbauer MG, Höfle MG (1998a) Significance of viral lysis and flagellate grazing as factors controlling bacterioplankton production in an eutrophic lake. Appl Environ Microbiol 64:431-438

Weinbauer MG, Höfle MG (1998b) Size-specific mortality of lake bacterioplankton by natural virus communities. Aquat Microb Ecol 15:103-113

Weinbauer MG, Peduzzi P (1995) Significance of viruses versus heterotrophic nanoflagellates for controlling bacteria.l abundance in the Northern Adriatic Sea. J Plankton Res $17: 1851-1856$

Weinbauer MG, Suttle CA (1997) Comparison of epifluorescence and transmission electron microscopy for counting viruses in natural marine waters. Aquat Microb Ecol 13: $225-232$ 
Weinbauer MG, Fuks D, Peduzzi P (1993) Distribution of viruses and dissolved DNA along a coastal trophic gradient in the Northern Adriatic Sea. Appl Environ Microbiol 59:4074-4082

Weinbauer MG, Fuks D, Puskaric S, Peduzzi P (1995) Diel, seasonal, and depth-related variability of viruses and dis-

Editorial responsibility: Fereidoun Rassoulzadegan, Villefranche-sur-Mer, France solved DNA in the Northern Adriatic Sea. Microb Ecol 59: $4074-4082$

Yentsch CS, Menzel DW (1963) A method for determination of phytoplankton, chlorophyll and phaeophytin by fluorescence. Deep-Sea Res 10:221-231

Submitted: August 13, 1998; Accepted: May 7, 1999

Proofs received from author(s): October 7, 1999 